\title{
Exploring Agricultural Intensification: A Case Study of Nigerian Government Rice and Cassava Initiatives
}

\author{
Ndianabasi Samuel Udondian ${ }^{1}$, Elizabeth Jane Zimilia Robinson ${ }^{2}$ \\ ${ }^{1}$ Emerging Businesses Department, Diamond Bank Plc., Lagos, Nigeria \\ ${ }^{2}$ School of Agriculture, Policy, and Development, University of Reading, Reading, United Kingdom
}

Email address:

udondiann@yahoo.com (N. S. Udondian), e.j.robinson@reading.ac.uk (E. J. Z. Robinson)

\section{To cite this article:}

Ndianabasi Samuel Udondian, Elizabeth Jane Zimilia Robinson. Exploring agricultural Intensification: A Case Study of Nigerian Government Rice and Cassava Initiatives. International Journal of Agricultural Economics. Vol. 3, No. 5, 2018, pp. 118-128.

doi: $10.11648 /$ j.ijae.20180305.14

Received: September 8, 2018; Accepted: September 28, 2018; Published: October 31, 2018

\begin{abstract}
Food security is a major challenge in sub-Saharan Africa. In Nigeria, the most populous country in the region, the rate of food production lags behind the rate of population growth, resulting in high incidences of hunger, with more than half the population living below the poverty line. In response to this, the Nigerian government has introduced a number of agricultural initiatives designed to increase food production and move the country closer to self-sufficiency. The objective of this paper is to determine the extent to which these initiatives have resulted in sustainable improvements in productivity. This is done through the development of a simple analytical framework that deconstructs increases in production into yield increases and area expansion. Rice and cassava are used as case studies. The paper demonstrates that three key government initiatives have had little impact on yields, with increases in production driven largely by area increases, most likely at the expense of forested areas and the ecosystem services they provide. The findings suggest that Nigeria has not achieved sustainable intensification of its agriculture for the two case study crops of cassava and rice. Moreover, some of the government initiatives assessed here have coincided with periods of falling yield.
\end{abstract}

Keywords: Agricultural Intensification, Food Security, Nigeria

\section{Introduction}

With increasing concerns about the state of the environment, the problem of providing food for the world's population becomes even more complicated, in part because agricultural practices often are found to have negative impacts on the environment. This raises the need for understanding whether and to what extent agricultural policies and practices harm, preserve, or enhance the environment. Sustainable intensification of agriculture seeks to increase the production of food on existing farmlands in ways that minimize impacts on the environment, conserve natural resources, and enhance the flow of ecosystem services so as not to compromise future food production prospects. Sustainable intensification recognizes the need for increased agricultural productivity to go hand-in-hand with the maintenance of ecosystem services and enhanced resilience to shocks [1]. The practice of increasing average input use of labour and/or capital on an agricultural land for the purpose of increasing the value of output obtained per unit of land, is increasingly a goal of sustainable intensification [2]. Yet in many countries there have been few efforts to determine whether specific initiatives have indeed resulted in sustainable (and sustained) improvements in productivity.

In Sub-Saharan Africa, there is an urgency in addressing food security, in part due to the reality that the rate of food production lags behind the rate of population growth, in part because the region has a particularly fragile natural resource base [3]. Nigeria has particular challenges. The country is home to around one fifth of the population of Sub-Saharan Africa [4]. Average population growth rate is $2.6 \%$ [5], which is higher than the rate of growth of food production. Indeed, growth in cereal production has stalled over the past ten years, impacting greatly on the country's food security situation, with over 53 million Nigerians, approximately $30 \%$ of the population, hungry and $52 \%$ living below the poverty line [4]. Whereas Nigeria was once a food self-sufficient country, and 
major exporter of food to other countries, it is today a net importer of food, with a yearly food import bill of US\$6.5billion, requiring approximately $7 \%$ of all export earnings [6].

Attempting to redress this situation, the government of Nigeria has introduced a number of initiatives in a bid to increase food self sufficiency, lower food import bills, improve the livelihoods of smallholder farmers, and eventually become a food exporter again [7, 8]. Many of these initiatives have aimed to increase production of key staples including cassava and rice. Conceptually this could be achieved by increasing yields, increasing the area planted to the crops, or a combination of the two. A focus on increasing yields implies agricultural intensification, a concept that may also include increasing cropping per unit of land, growing multiple crops per year, synthetic variety usage and mechanization, and changing land use from low value crops to high value crops, thus increasing the economic efficiency of land usage $[9 ; 10]$. Such intensification can be part of a strategy for reducing agriculture encroaching into forest lands, whilst satisfying the agriculture needs of the people [11]. It is considered a vital tool for meeting the food demands of the world's growing population [12], without compromising off-farm ecosystem services such as biodiversity conservation and carbon sequestration.

Using Nigeria as a case study, this paper assesses three specific agricultural programmes, each of which aimed to increase domestic food production, with respect to the extent to which production increases have been driven by land expansion, yield increases, or both.

This paper develops and presents a simple analytical framework in which changes in total production is deconstructed into changes in area planted to the crop and changes in yield, for cassava and rice, two particularly important crops.

Cassava is a major food crop in the tropics, providing energy for more than 200 million people [13]. It is the second most important food crop in the African diet [3], and one of the cheapest sources of calories for both human nutrition and animal feeding [14]. Nigeria is the world's largest cassava producer, yet productivity remains low [15]. The country has thus continuously sought to realize the full potential of the crop through the implementation of numerous intervention programs. Nigeria is one of the leading rice producers in the African continent but also Africa's largest rice importer [16], spending over US\$300 million annually on rice imports [17]. Demand for rice in Nigeria is increasing at an average annual rate of $11 \%$ [18]. This increase is driven in part by population growth, but also due to growth in incomes, urbanization, and the associated expansion of fast food restaurants [19]. Attaining self-sufficiency in rice production has remained a priority for Nigeria as it seeks to save on its food import bills.

For both cassava and rice, the three government initiatives analysed have resulted overall in increased production, an important element of increasing food security through reduced reliance on imports. However, most of this increase has come about through land expansion rather than yield improvements, suggesting a possibly negative impact on environmental sustainability, and little improvement in the sector's competitiveness. The following section provides detail on the three initiatives. Methodology, including the conceptual framework is presented in section 3, findings are presented in section 4 and section 5 concludes.

\section{Nigeria: A Case Study}

Changes in land use patterns have been identified as the second-largest source of human induced greenhouse gas emission [20]. Expansion of agricultural land increasingly compromises forested areas, raising concerns about potential loss of biodiversity and carbon sequestration provided by forests [21]. Most growth in crop production by smallholder farmers in Nigeria, and throughout the region, has historically been driven by area expansion into forest land, rather than yield increase [22, 23].

Yet though this problem has been recognised in Nigeria for decades, for example, over forty years ago by Kio [24], little research attention in the country is given to land use change studies. Exceptions include Abbas who highlight how agricultural land expansion reduces important environmental services [25]. For example, they find that in Kafur, Katsina state, between 1995 and 2008, the built-up area increased by $1.8 \%$, and agricultural land by $28.2 \%$, whilst the water body (rivers and streams) decreased by $24.7 \%$. In Calabar river catchment of south-eastern Nigeria, forestland shrank by $69 \%$ between 1967 and 2008, most being replaced by agricultural land [26]. In south-western Nigeria, derived savannah and high forests declined by $72 \%$ and $8 \%$ respectively between 1986 and 2002, whereas those under shrub /farmland complex and settlement/bare surface increased by $414 \%$ and $192 \%$ respectively, an indication of encroachment of agricultural land and settlement into forest areas and derived savannahs [27].

The Nigerian government since independence in 1960 has embarked on numerous agricultural programs aimed at attaining food security and food self-reliance [28]. It is also currently actively working towards diversifying away from oil, and agriculture is one of the key economic sectors being targeted. Some of these programs have been solely funded by the Nigerian government and others have been carried out in partnership with development agencies [7]. These programs have been largely similar, varying only in nomenclature and organizational structure, emphasising variously food security, export of agricultural products, provision of extension services to rural dwellers, agricultural support and rural development services [8]. They have focused on different elements, including the provision of fertilizers, pesticides and improved planting materials; provision of irrigation facilities; making credit facilities accessible to farmers; and market restructuring. Whilst these programs have not stated "sustainable intensification" in clear terms as targets, many of the planned approaches are in keeping with the ideals of agricultural intensification; incorporating chemical fertilizers, pesticides and irrigation technology, and leading to higher 
yields [29].

These three programs are largely believed to have performed below expectations [8]. Explanations include weak agricultural policy, lack of stakeholder involvements, top-down approach in project implementation, lack of continuity by successive governments, short duration of projects, delay, embezzlement and misappropriation of funds, poor project monitoring, and poor extension service network, among others $[8,30,31]$. Yet despite not meeting their targets, these projects have been reported as having had a positive impact on agricultural production levels in Nigeria. For example, Daneji cites increases in the area cultivated and crop output of sorghum, rice and cassava as evidence [30]. African Development Fund (ADF) also reports production increases of up to $300 \%$ in some cases resulting from the implementation of the "fadama project", a World Bank assisted project in Nigeria aimed at promoting the adoption of simple and low-cost improved irrigation technology by local farmers along low-lying plains, known in the Hausa language as fadama [32].

The Presidential Initiative on Agriculture (PIA) (2002-2007) sought to restore the agricultural sector to its pre-oil boom levels by promoting growth in production, processing, marketing and utilization of some target crops and livestock, aiming to position the country for a re-entry into the food export market. The program targeted cassava, rubber, maize, tropical fruits, cotton, vegetable oil, cocoa, livestock and fisheries $[33,34,15]$.

The vision of the National Agriculture and Food Security Strategy (NAFSS), implemented 2008 through 2011, had the central aim of ensuring sustainable access, availability, and affordability of quality food for all Nigerians. It aspired to address the challenges of inadequate infrastructure, limited access to improved technologies, financial market weakness, resource market failures and organizational and government constraints by instituting investment climate reforms. The program also sought to raise agricultural productivity and promote agricultural exports. The crops targeted include; cassava, rice, millet, sorghum, wheat, maize, sugar, cowpeas, soybeans, tomato, cotton, cocoa and oil palm [35].

The specific objective of the Agricultural Transformation Agenda (ATA), implemented 2011 through 2015, was to increase the income of small holder farmers and rural entrepreneurs engaged in the production, processing, storage and marketing of priority commodity value chains. This initiative supported private-sector led agricultural growth for food security, creation of jobs and shared wealth. The priority crops under ATA included rice, cassava, sorghum, cocoa, cotton, maize, oil palm, onions, soybeans and tomatoes [17].

\section{Methods and Data Sources}

Whilst many dimensions of agricultural intensification are recognized; encompassing reducing negative impacts on the environment, increasing natural capital and improving the circulation of environmental services $[9,36]$, this paper focuses on the extent to which changes in production occurs with or without area expansion. As such it is closely linked to one of three basic principles of sustainable intensification, which is the increase in production of food, fibre, fuel and feed per unit of land, labour and capital $[34,37]$. It also links closely to the definition of productivity as the ratio of the value of total farm output to the value of total farm inputs used in production [23].

The conceptual framework developed and employed in this paper is deliberately kept simple, so that it can be used as a quick diagnostic tool where detailed data are hard to come by. Total production of a specific crop, Q, is equal to the product of area cultivated A and yield $\mathrm{Y}$. A change in total output of a crop is thus decomposed into a combination of a change in yield and a change in area. Yield-led production growth is desirable with respect to land because it indicates that agriculture is intensifying, productivity is increasing, and agriculture is more sustainable with respect to land use patterns. Naturally, this paper recognizes that this is only one dimension of sustainable intensification. Mathematically:

$$
\begin{gathered}
Q=A * Y \\
Q^{\prime}=(A+\Delta A)(Y+\Delta Y) \\
\Delta Q=A \Delta Y+Y \Delta A+\Delta Y \Delta A
\end{gathered}
$$

Equation 3 simply clarifies that a change in production can come about due to changes in area and changes in yield. Whether area and yield increase or decrease determines the extent to which an increase in production is sustainable with respect to land use. This is illustrated in Figure 1 and Figure 2. The $\mathrm{x}$ axis represents the area of production of a particular crop, and the $y$ axis represents total production of that crop and yield of that crop respectively. Thus the slope of the curve in Figure 1 represents yield, as presented in Figure 2. One can consider movement along any particular trajectory as movement across time.

Figure 1 and Figure 2 show a number of different trajectories. "A" represents a scenario in which production increases whilst yield remains constant, thus all growth in production is due to area increase, an example of extensification. In "B", yield declines and area increases, but the decline in yield is not sufficient to reduce total production, which continues to increase. Thus in " $\mathrm{B}$ " the objective of increased food production is achieved (as it is for "A"). However, this is achieved with lower average efficiency suggesting the country may be becoming less competitive. Further, if the expansion is into forested areas, there may be a cost in lost ecosystem services.

In " $C$ " and " $D$ ", as area increases, yields are falling to the extent that total production is constant or falling, respectively. This would indicate a programme that failed across multiple dimensions of increasing food production and food productivity. In contrast, in "F", yield, area, and total production increase. This could reflect a successful programme in which farmers observe increased productivity and so are encouraged to expand the area planted to the specific crop. The impact at a landscape level would depend in 
part on whether the increased expansion displaces other less profitable crops or forest land.

Finally, in "E", production increases and is due only to increases in yields rather than area. Trajectories $\mathrm{E}$ and $\mathrm{F}$ can be considered examples of agricultural intensification, due to increasing yields. Whether a trajectory is sustainable depends on the extent to which the area planted to this crop is increasing, and what is being displaced by any specific crop expansion, specifically whether this expansion is at the expense of a less profitable crop, or into forest land; and any environmental damage caused by increasing input intensity.

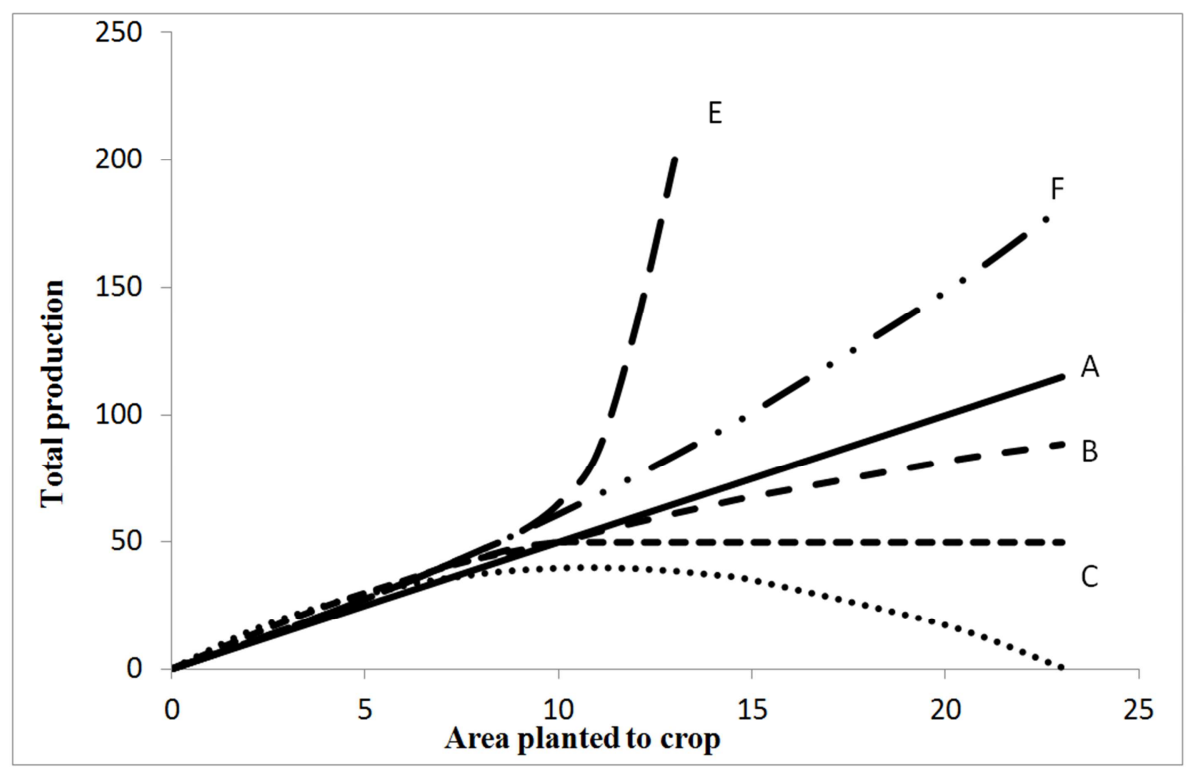

Figure 1. Illustration of conceptual framework for various production-area trajectories.

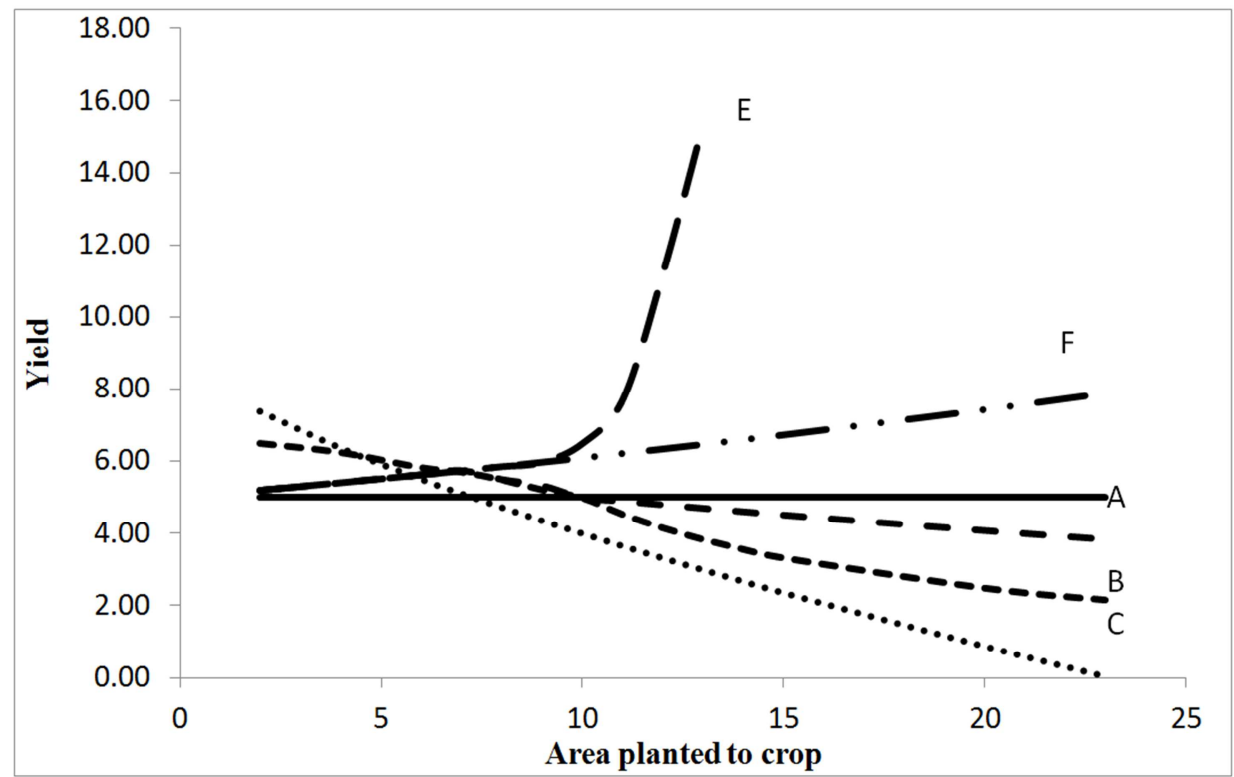

Figure 2. Illustration of conceptual framework for various possible yield-area trajectories.

Using this framework, trends of production, productivity, and sustainability, for cassava and rice in Nigeria are explored across time, for the three recent intervention programmes. The study uses secondary data obtained from the Food and Agricultural Organization (FAO) statistical website.

\section{Findings}

Total cassava production has generally followed an upward trajectory since 1990. The national level data suggest that production was fairly flat in the 1990s but that there was a steady increase in production from the onset of the PIC programme in 2002, until 2006 (Figure 3). The second initiative, NAFSS, is linked to stable or falling yields between 2006 and 2011. The recent ATA initiative appears to show yields increasing again, though data are only available up to 2014. 


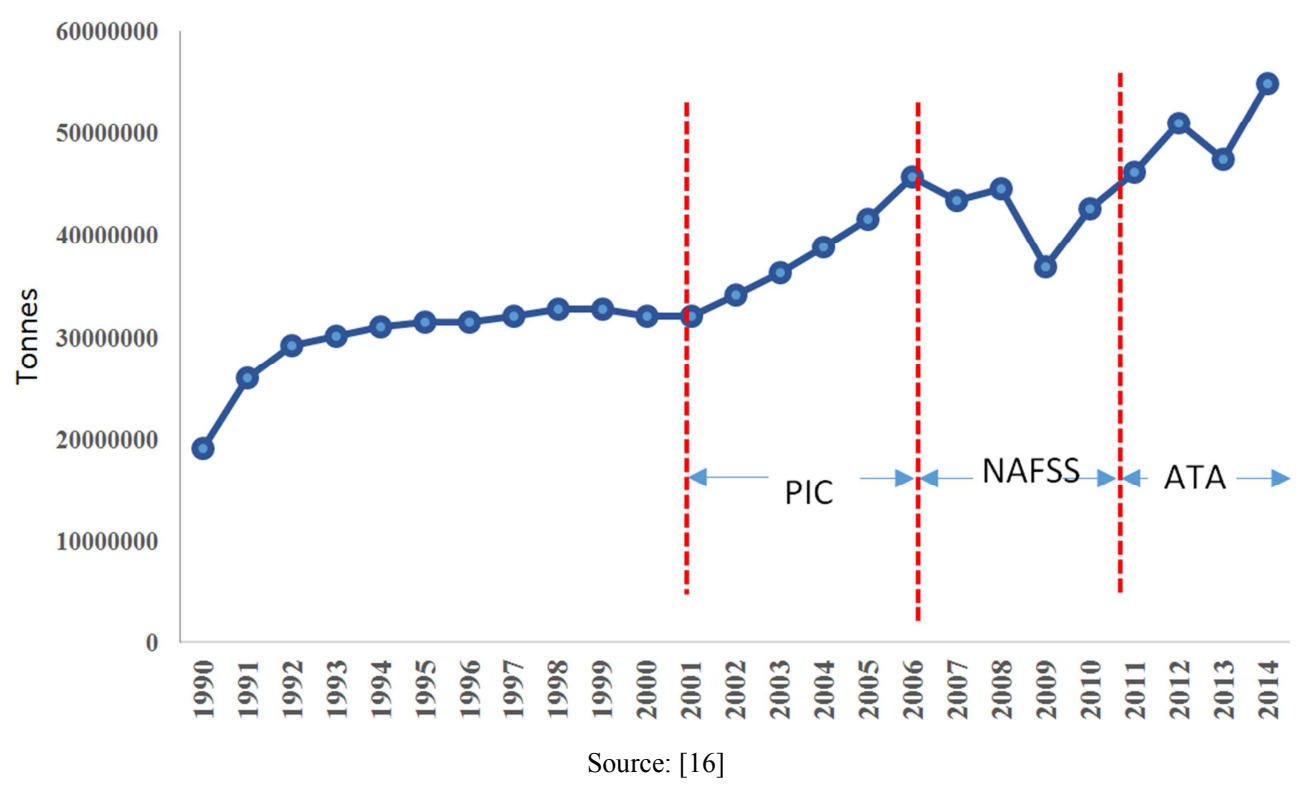

Figure 3. Total cassava production (tonnes), Nigeria, 1990-2014.

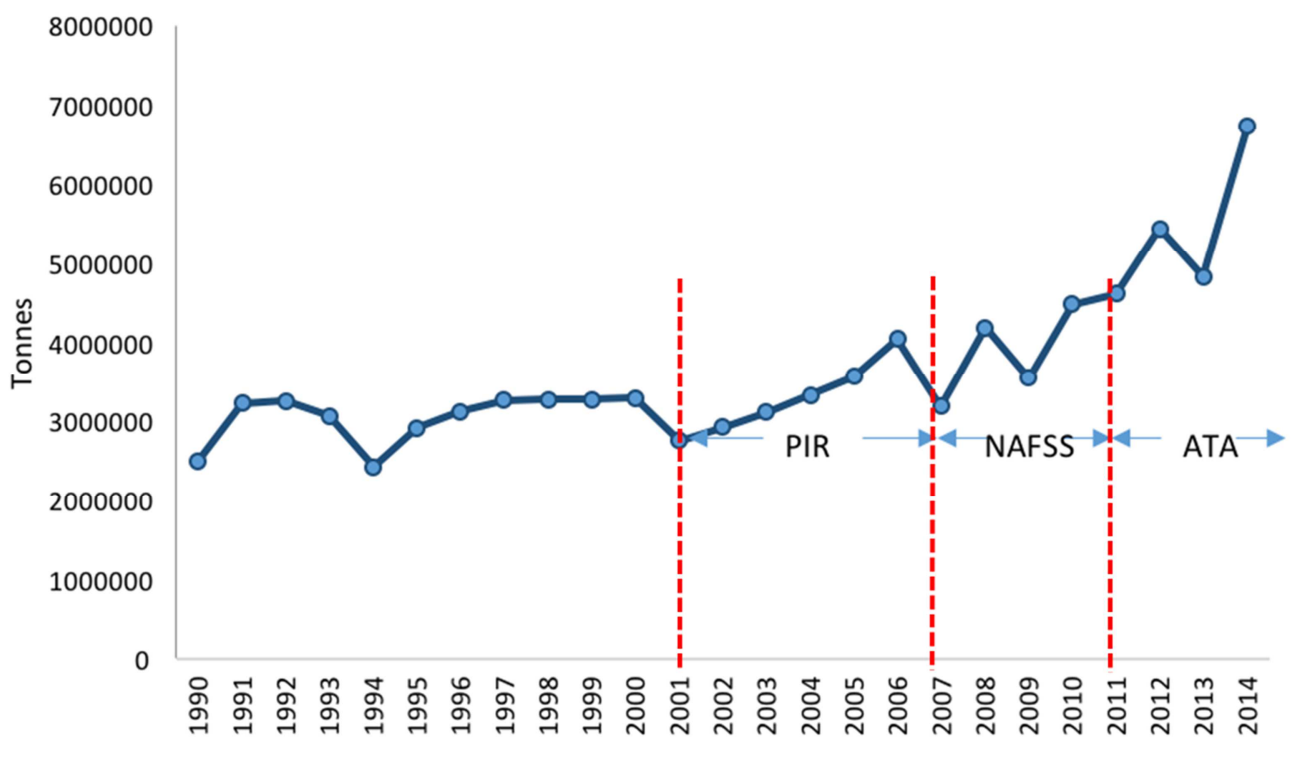

Figure 4. Total rice production (tonnes), Nigeria, 1990-2014.

Rice production in Nigeria appears to have been relatively flat between 1990 and 2001 (Figure 4). The advent of the three successive government interventions appears to coincide with production steadily increasing after this.

\subsection{Yield and Area Contributions to Production Growth for Cassava}

In 2002, at the advent of the first of the three programmes addressed in this paper, the area under cassava cultivation in Nigeria was 3.3 million hectares. By 2014, this area had increased to 7.1 million hectares. Yet this more than doubling of area was accompanied by only around a $61 \%$ growth in production, and thus a fall in average yield. A decomposition of production growth into changes in yield and area reveals that the contribution of yield increases to increases in cassava production has been on a downwards trend, while the contribution of area expansion has been on an upwards trend (Table 1). On average, average cassava yield for Nigeria during the Presidential Initiative on Cassava stood at just over ten tonnes per hectare. Although a small increase in yield can be observed, this crop performed considerably below the yield potential for cassava and the program's yield target of 30 tonnes per hectare, which itself is below the yield potential for cassava, under optimal conditions, of 80 tonnes per hectare [38]. Overall the crop performed more than $60 \%$ below program target.

The four years under National Agriculture and Food Security Strategy (NAFSS) saw fluctuations in the performance of cassava in terms of yield, area cultivated and total quantity produced. During this program cassava recorded its highest yield of 12.2 tonnes per hectare, still well below 
target. Overall there was little change in yield or area cropped. The change under the Agricultural Transformation Agenda (ATA) appears particularly unsustainable with increased production driven by a large area expansion and a fall in average yield. Overall the crop has followed a trajectory that fits with the unsustainable path B (Figure 2). This supports the position that in Sub-Saharan Africa, increase in agricultural production is led mostly by area expansion rather than yield increase [23].

Table 1. Area and yield contributions to cassava growth.

\begin{tabular}{|c|c|c|c|}
\hline & Average yearly growth in production & Yield contribution & Area contribution \\
\hline Presidential Initiative on Cassava (PIC) & $5.1 \%$ & $72.1 \%$ & $26.9 \%$ \\
\hline National Agriculture and Food Security Strategy (NAFSS) & $2.4 \%$ & $29.6 \%$ & $69.3 \%$ \\
\hline Agricultural Transformation Agenda (ATA) & $3.4 \%$ & $-16.9 \%$ & $115.4 \%$ \\
\hline
\end{tabular}

These changes are explored in more detail in Figure 5, using the framework for deconstructing changes in total production. It can be seen explicitly from Figure 5 that before the PIC initiative, cassava yields were relatively stable, with some evidence that they were on the decline. During the PIC, yields increased but there was little increase in cropped area. The
NAFSS period saw yields on a flat to downwards trend again with little change in the cropped area. In contrast ATA is associated with a rapid increase in cropped area but a fall in average yields. Overall however, production has increased, which seen in isolation could be construed as a successful outcome for the programmes.
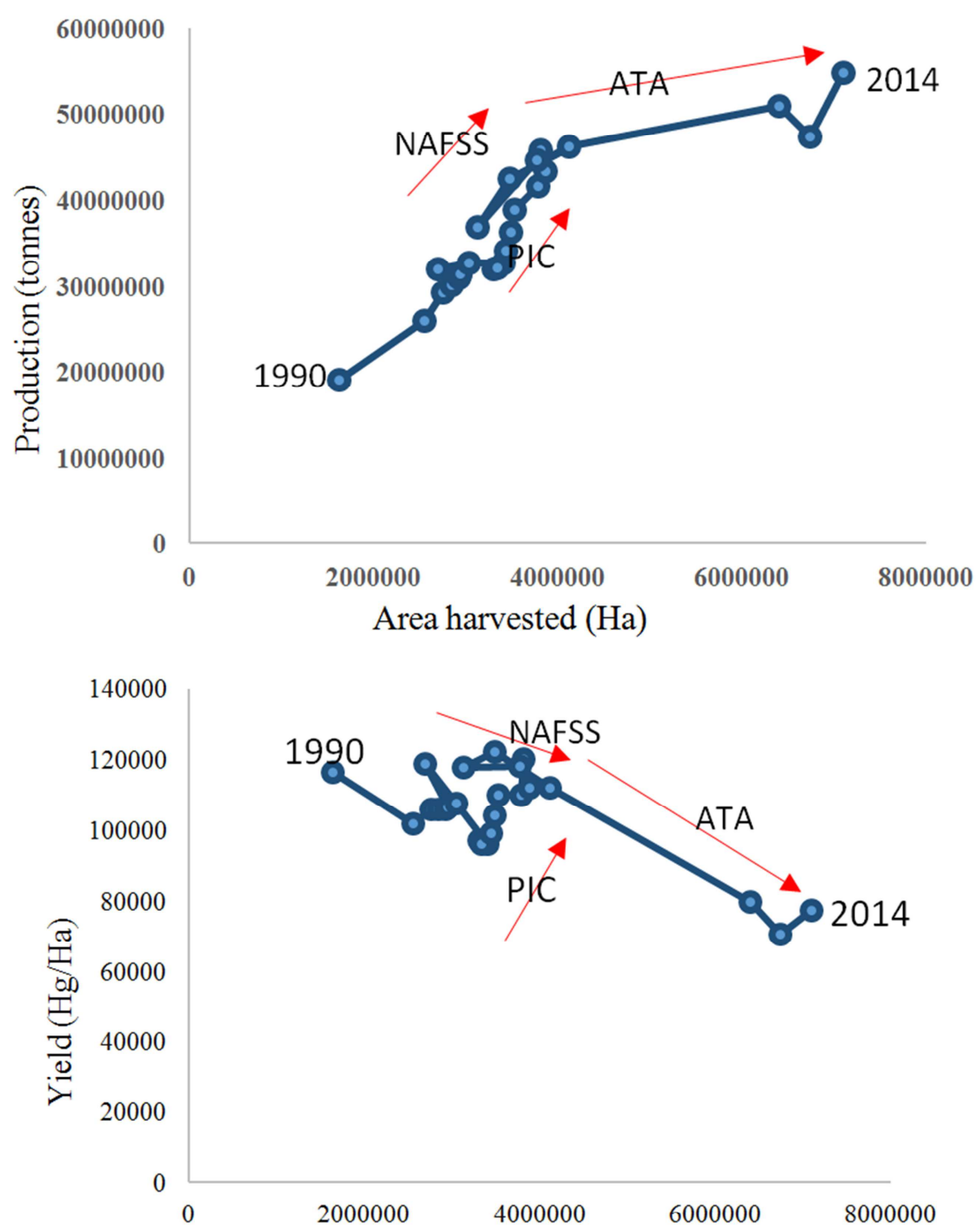

Area harvested (Ha)

Source: [16]

Figure 5. Production-area (a) and yield-area (b) trajectory for cassava. 


\subsection{Yield and Area Contributions to Production Growth for Rice}

Increases in rice production, unlike for cassava, have been driven by both yield and area increases. Table 2 presents the average growth in production during the intervention programs, and the yield and area contributions to this growth. In 2002, at the inception of the Presidential Initiative on Rice (PIR), rice production stood at approximately 2.9 million tons. This increased to approximately 6.7 million tons in 2014 with area cultivated increasing by approximately $40 \%$ and yield by $60 \%$.

Table 2. Area and yield contributions to growth in rice production.

\begin{tabular}{|c|c|c|c|}
\hline & Average yearly growth in production & Yield contribution & Area contribution \\
\hline Presidential Initiative on Rice (PIR) & $3.2 \%$ & $39.4 \%$ & $60.5 \%$ \\
\hline National Agriculture and Food Security Strategy (NAFSS) & $11.3 \%$ & $89.5 \%$ & $12.9 \%$ \\
\hline Agricultural Transformation Agenda (ATA) & $39.6 \%$ & $54.3 \%$ & $46.7 \%$ \\
\hline
\end{tabular}
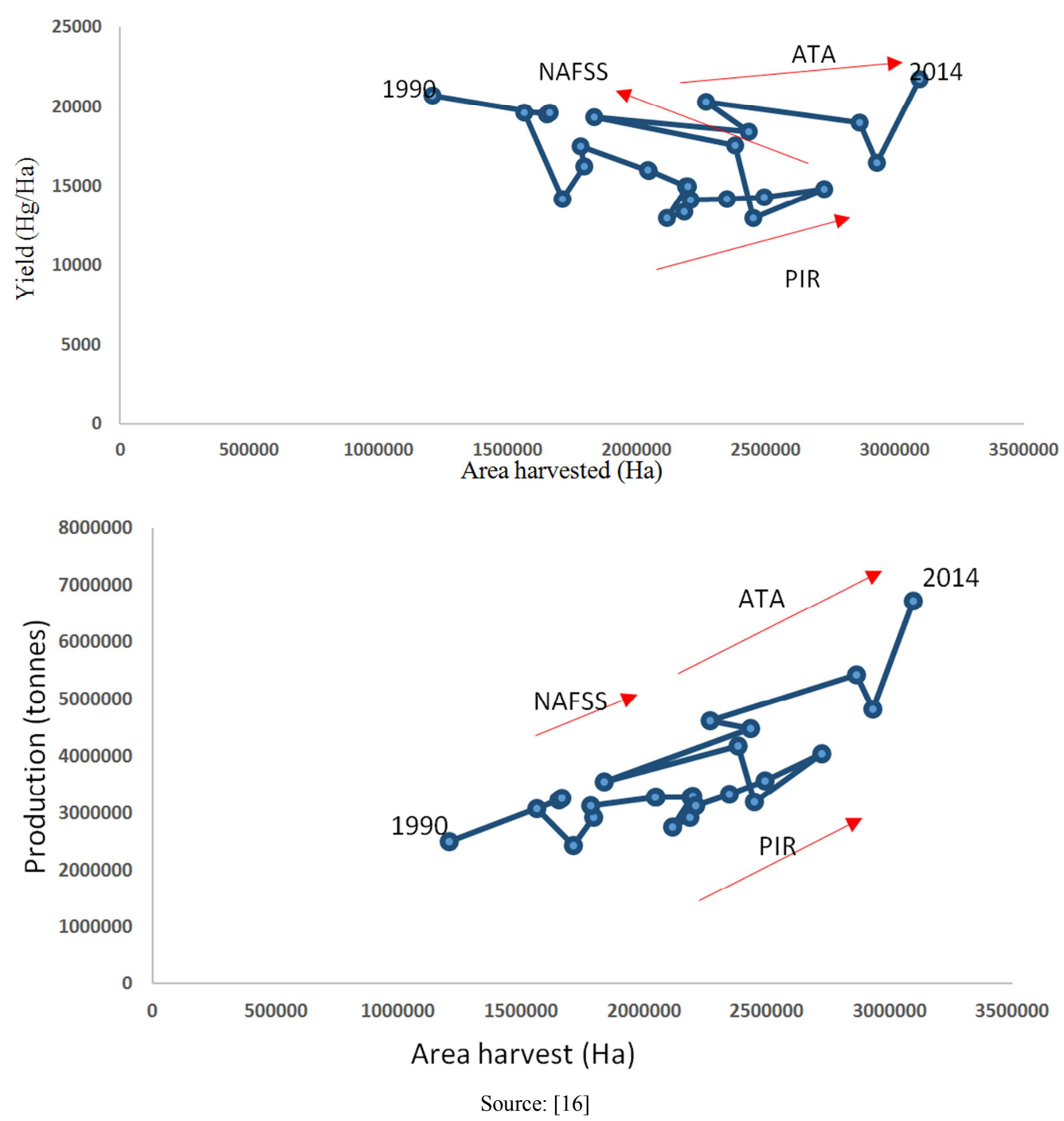

Figure 6. Production-area (a) and yield-area (b) trajectory for rice

The implementation of the National Agriculture and Food Security Strategy (NAFSS) similarly saw growth in rice production, driven mainly by yield increases, with some evidence of total area to rice falling. Yields continued to increase during the implementation of the Agricultural Transformation Agenda (ATA), with yield increases being matched by area increases (Figure 6). Rice is currently the highest cash crop income generator for Nigerian farmers [38], yet yields remain low, at just 1.63 tonnes/ha [16], and most of the growth in production has still been driven by area rather than yield growth

In 2013, Nigeria imported just under 2.2 million tons of rice [38]. If rice production maintains its best yield performance of 2.18 tons/ha, an additional 1 million hectares of land would be required for the country to achieve its aim of self sufficiency, not taking into account any increase in demand for rice in the country. 


\section{Discussion}

Total crop production, productivity, and impact on the environment, are each important aspects of agricultural policy in Nigeria. This research has demonstrated that three government initiatives with respect to cassava and rice have coincided with increases in production, but have had little impact on yields whilst resulting in relatively large increases in area cropped.

\subsection{Impact on Forest Area}

An important question is into what types of land is cassava and rice production expanding. In the period between 2002 and 2014, an additional 3.7million hectares of land was converted for cassava production while just under one million hectares was added to rice production. African Development Bank, while assessing what it referred to as the cassava revolution in Nigeria, inspired by the Presidential Initiative on cassava, suggested that increase in land for cassava production was made possible by a decrease in the hectares of land made available for other crops [15]. However, an assessment of the trend of land cultivated for most food and cash crops in Nigeria shows that for the most part, fluctuations in area cultivated followed a similar trend as exhibited by cassava. A few crops such as sorghum and millets have experienced declines in area cultivated, but these declines did not mirror the increases in area cropped to cassava.

Forest area has been declining in Nigeria. In 2002, the country's total forest land was 12.3 million hectares, but had fallen to 6.99 million hectares by 2015 [16]. It is highly probable that the continued expansion of agricultural land is encroaching into forest land, as the biggest source of deforestation in the tropics is agriculture [20]. The rate of forest loss in Nigeria has also been attributed to indiscriminate conversion of forest land into agricultural use and fuel wood extraction from the forests [35]. This continuous decline in forest results in higher greenhouse gas emissions, and loss of biodiversity and other important ecosystem services $[1 ; 21]$.

\subsection{Impact on Yields}

Typically, agricultural intensification requires a combination of credit, subsidized fertilizer, seeds, irrigation, and agricultural extension programs [39]. In Nigeria, cassava farmers with access to credit have been found to have higher productivity than those without [40]. Policies that enhance access to credit might therefore be expected to have a positive impact on productivity growth. Of the three cassava schemes discussed above, the Presidential Initiative on Agriculture did not include credit schemes as one of its action plans. In contrast, NAFSS proposed different lending packages for different farmers based on the size of their farms. Large scale farmers were to gain access to credit from a fund set aside for financing farm-set up and capital acquisition, while medium and small-scale farmers received direct funding support from the government. ATA introduced a Nigerian Incentive-based Risk Sharing for Agricultural Lending (NIRSAL) scheme which sought to improve the agricultural value chain by encouraging lending through offering incentives. NIRSAL was based on some pillars aimed to "de-risk" agricultural lending and cover the cost of lending. US\$500 million was budgeted to run the pillars. Possible explanations for why these credit programs did not improve yields are poor program implementation and paucity of funds; and poor conceptualization and inefficient implementation of intervention programs [41]. Furthermore, generally public expenditure allocations to agriculture in Nigeria have been static or declining, and the country has never met the AU recommendations of $10 \%$ [42].

Fertilizer use in Nigeria is very low, on average around $13 \mathrm{~kg} / \mathrm{ha}$, much lower than the world average of $100 \mathrm{~kg} / \mathrm{ha}$ and Asian average of $150 \mathrm{~kg} / \mathrm{ha}$ [36]. Evidence from the 80 millennium villages operating across 10 African countries suggests yields increase with increased fertilizer applications. In Malawi for instance, fertilizer application alongside other improved agronomic practices increased average maize yield from 1 tonne/ha to more than 3 tonnes/ha, relative to no increased application of fertilizer [43]. Subsidised fertilizer was one of the major components of each of the three programs considered here. The approach to PIA Initiative on Agriculture's subsidy program was public-sector driven, providing a $50 \%$ subsidy on fertilizers as well as planting materials. This subsidy regime was similarly adopted through the NAFSS. However, only $11 \%$ of targeted farmers were able to access the subsidized fertilizer and other inputs under this program [33]. The subsidy regime under the ATA was designed to correct the loop holes of the PIA subsidy regime [17]. It deregulated the fertilizer and seed sub-sector and sought to sanitize the fertilizer subsidy program. A pilot of the new subsidy strategy (the voucher program) claimed to get fertilizers across to $94 \%$ of actual farmers. Yet most of the fertilizer subsidy regimes in Nigeria were characterized by poor fertilizer quality, and delays in fertilizer distribution [44].

Irrigation has the potential of raising agricultural productivity in Africa [45]. The Fadama project, a World Bank-led irrigation program in Nigeria targeting low-lying plains, was found to increase production by up to $300 \%$ with attendant yield increases [32]. In the Philippines, small-scale irrigation systems in low-lands increased labour demand and wages, thus pulling labour out of a more extensive agricultural sector in the uplands and reducing forest clearing in the low-lands by almost 50\% [39] In recognition of the importance of irrigation to production and productivity growth, the three Nigerian programs all included rehabilitation and expansion of irrigation facilities in the country. However, the irrigation facilities were either operating sub-optimally or not at all, in part because irrigation projects in Sub-Saharan Africa tend to be more expensive and perform less satisfactorily than in other regions [46].

The three programmes also included large-scale private-sector-led land acquisition. The Cassava Growers Association (CGA) acquired 545,000 ha of land for cassava cultivation across the country as their contribution to the Presidential Initiative on Cassava [47]. It is unclear how the acquired land was distributed among farmers and at what cost 
if at all. However, it would suggest that it was easier for farmers to extensify rather than intensify on their existing land [48].

Land management took a back-seat in the intervention programs under review. The PIA did not feature land management as one of its objectives. NAFSS however paid attention to land management, proposing to carry out nation-wide soil and fertility tests. Fertilizers would be distributed based on the results of these tests and farmers would be guided on the application of the right quantities. It also sought to reclaim degraded agricultural lands. But whereas yield and production targets were set and timelines drawn, the land reclamation proposition and soil testing did not have targets or timelines. Further, it is unclear whether these land management strategies were given any attention because there is no documented evidence to that effect.

The ATA also factored in the environment in its action plan. It proposed to facilitate reforestation and better catchment management in the hinterlands, by supporting tree nurseries and fencing off protected areas. It also sought to promote the use of organic fertilizer by supporting its commercialization. To what extent area expansion of a number of crops is compatible with forest protection is not considered explicitly. This may be due to a lack of adequate knowledge of the country's land use situation as the country gives very little recognition and research attention to land use studies [26]. Further, the notion that only $40 \%$ of the country's arable land is being cropped [49] does not create an urgency for better land management practices. Where land is abundant, extensification is often a rational strategy [2]. However, this ought not dissuade the government from making effective conservation moves especially with the country's high population growth rate, as intensification pushed by population pressure is likely to have greater negative impacts on the environment, as compared to intensification in response to policies and incentives.

Agricultural intensification itself can lead to environmental damage if there is high dependence on inputs such as inorganic fertilizer and pesticides; potential high susceptibility to pest and disease out-breaks if the distribution of high yield varieties create homogeneity that facilitate spread of diseases and pests; and wide-spread resistance to chemical treatments [10]. Agricultural intensification has also been identified as a major driver of worldwide biodiversity losses [50] and could fuel extensification through raising cost of land rents due to high productivity increase, thus serving as an incentive for agricultural land expansion and deforestation [11].

\section{Conclusion}

The ability of a country to grow its own food is often seen as an important element of food security, especially in the wake of recent global food crises. Indeed, "cereal dependency ratio" is one of the FAO's food security indicators. Yet if increases in total production are not accompanied by increased yields, but rather by expansion of area cropped, countries may in the longer term be disadvantaged, both with respect to the competitiveness of domestic production and the likely negative impact that such area expansion can have on the broader landscape, especially if at the cost of forest-based ecosystem services such as biodiversity and carbon sequestration. This paper has developed and presented a simple framework that has been used to analyse the impact of three initiatives in Nigeria, which aimed to increase the production of rice and cassava, so as to improve the country's food security. The analysis has shown that increases in total production can mask negative outcomes. Falling cassava yields imply losses in productivity and thus competitiveness of the sector. Increases in total production combined with area expansion suggest a particularly unsustainable pathway towards increasing domestic food supply.

Naturally, this paper recognizes that agricultural intensification itself could fuel extensification. These observations notwithstanding, the three programmes considered almost certainly have had a negative impact on land use, with little positive impact on yields. The paper questioned not just to what extent production has increased, but whether this has been due to yield increases or area expansion. It was found that the three programmes have been lacking across important dimensions of sustainable intensification and food security.

\section{References}

[1] Garnett, T., Appleby, M., Balmford, A., Bateman, J., Benton, T., Bloomer, P., Burlingame, P., Burlingame, B., Dawkins, M., Dolan, L., Fraser, D., Herrero, M., Hoffmann, I., Smith, P., Thornton, P., Toulmin, C., Vermeulen, S., Godfray, H. (2013). Sustainable Intensification in Agriculture: Premises and Policies. Science Magazine, 341(July), 33-34.

[2] Erenstein, O. (2006). Intensification or Extensification? Factors Affecting Technology Use in Peri-urban Lowlands Along an Agro-ecological Gradient in West Africa. Agricultural Systems, 90, 132-158.

[3] Nweke, F., Dunstan, S., Spencer, C., Lynam, J. (2002). The Cassava Transformation: Africa's Best Kept Secret. Michigan State University Press.

[4] Uma, K., Eboh, F., Obidike, P., Ogwuru, H. (2014). Stimulating Food Production in Nigeria for Sustainable Development. American Journal of Scientific and Industrial Research, 5(3), 88-96.

[5] UNFPA. (2016). State of World Population. [Online] Available at: http://www.unfpa.org/swop [Accessed 18 July 2016].

[6] Federal Ministry of Agriculture and Rural Development (2016). Annual Report.

[7] Ugwu, D., Kanu, O. (2012). Effects of Agricultural Reforms on the Agricultural Sector in Nigeria. Journal of African Studies and Development, 4(2), 51-59.

[8] Agber, T., Lortima, I., Imbur, E. (2013). Lessons from Implementation of Nigeria's Past National Agricultural Programs for The Transformation Agenda. American Journal of Research Communication, 1(10), 238-253. 
[9] Pretty, J., Toulmin, Camilla., Williams, S. (2011). Sustainable Intensification in African Agriculture. International Journal of Agricultural Sustainability, 9(1), 5-24.

[10] Defries, R., Fanzo, J., Remans, R., Palm, C., Wood, S., Anderman, T. (2015). Metrics for Land-scare Agriculture. Science, 349(6245), 238-240.

[11] Phelps, J., Carrasco, L., Webb, E., Koh, L., Pascual, U. (2013). Agricultural Intensification Escalates Future Conservation Costs. Proceedings of the National Academy of Sciences of the United States of America, 110(19), 7601-7606.

[12] FAO (2013). Save and Grow Cassava. [Online] Available at: http://www.fao.org/3/a-i3278e.pdf [Accessed 27 July 2016].

[13] Taiwo, K. (2006). Utilization Potentials of Cassava in Nigeria: The Domestic and Industrial Products. Food Reviews International, 22(1), 29-42.

[14] Tonukari, N. (2004). Cassava and the Future of Starch. Electronic Journal of Biotechnology, 7(1), 5-8.

[15] Philip, D., Ayanwale, A., Olusi, J. (2014). Drivers of Success for CAADP Implementation: Nigeria Case Study. African Development Bank.

[16] FAOSTAT. (2016). Production Quantities by Country. [Online] Available at: http://faostat3.fao.org/download/Q/QC/E [Accessed 14 July 2016].

[17] Federal Ministry of Agriculture and Rural Development (2011) Agricultural Transformation Agenda Action Plan.

[18] Erhabor, P., Ojogho, O. (2011). Demand Analysis for Rice in Nigeria. Journal of Food Technology, 9, 66-74.

[19] Daramola, B. (2005). Government Policies and Competitiveness of Nigerian Rice Economy. Workshop on Rice Policy \& Food Security in Sub-Saharan Africa, Cotonou, Republic of Benin.

[20] Don, A., Schumacher, J., Freibauer, A. (2011). Impact of Tropical Land-use Change on Soil Organic Carbon Stocks - A Meta-analysis. Global Change Biology 17(4), 1658-1670.

[21] Dobrovolski, R., Loyola, R., DaFonseca, G., Diniz-filho, J., Araujo, M. (2014). Globalizing Conservation Efforts to Save Species and Enhance Food Production. Bioscience, 64(6), 539-545.

[22] Diao X., Nwafor, N., Alpuerto, V. (2010). Strategic Issues on Growth in the Agricultural Sector and Reducing Poverty in Nigeria. Nigeria Strategy Support Program (NSSP) Brief No. 10. International Food Policy Research Institute (IFPRI).

[23] Vanlauwe, B., Coyne, D., Gockowski, J., Hauser, S., Huising, J., Masso, C., Nziguheba, G., Schut, M., Asten, P. (2014). Sustainaible Intensification and the African Smallholder Farmer. Current Opinion in Environmental Sustainability, 8, $15-22$

[24] Kio, P. (1972). Shifting cultivation and multiple use of forest land in Nigeria. The Common Wealth Forestry Review, 51(2), 144-148.

[25] [Abbas, I., Muazu, K., Ukoje, J. (2010). Mapping Land Use Land Cover Change Detection in Kafur Local Government, Katsina, Nigeria (1995-2008) Using Remote Sensing and GIS. Research Journal of Environmental and Earth Sciences, 2(1), 6-12.
[26] Effiong, J. (2011). Changing Pattern of Land Use in the Calabar River Catchment, South-eastern Nigeria. Journal of Sustainable Development, 4(1), 92-102.

[27] [Mengistus, D., Salami, A. (2007). Application of Remote Sensing and GIS in Land Use/land Cover Mapping and Change Detection in a Part of South Western Nigeria. African Journal of Environmental Science and Technology, 1(5), 99-109.

[28] Tiri, G., Ojoko, E., Aruwayo, A. (2014). Growth Enhancement Support Scheme (GESS) and the Challenges of Food Security in Nigeria: A Review. ARPN Journal of Agriculture and Biological Science, 9(7), 226-232.

[29] Giovanni, A. (1985). Farm Size, Land Yields, and the Agricultural Production Function: An Analysis for Fifteen Developing Countries. World Development, 13(4), 513-534.

[30] Daneji, I. (2011). Agricultural Development Intervention Programmes in Nigeria (1960 To Date): A Review. Savannah Journal of Agriculture, 6(1), 101-107.

[31] Olaolu, M., Akinnagbe, O. (2014). Constraints and Strategies for Improving Agricultural Intervention Programmes in Nigeria: A Case of National Fadama Development Project Phase 2, Kogi State, Nigeria. Journal of Agricultural Extension, 18(2), 164-176.

[32] African Development Fund (2003). Republic of Nigeria FADAMA Development Project Appraisal Report [Online] Available at:

http://www.afdb.org/fileadmin/uploads/afdb/Documents/Proje ct-and-Operations/NG-2003-156-EN-ADF-BD-WP-NIGERIA -AR-FADAMA-DEVELOPMENT-PROJECT.PDF [Accessed 22 July 2016].

[33] Anyanwu, C., Amoc, B., Odey, L., Adebayo, O. (2011). An Assessment of the Operations of the Presidential Initiatives on Agriculture in Nigeria: 2001-2007. Central Bank of Nigeria, Occasional Paper, No. 40.

[34] Philip, D., Nkonya, E., Pender, J., Oni, O. (2009). Constraints to Increasing Agricultural Productivity in Nigeria: A Review. Nigeria Strategy Support Program Background Paper No. NSSP 006. International Food Policy Research Institute (IFPRI).

[35] Federal Ministry of Agriculture and Rural Development (2010). National Agriculture and Food Security Strategy Policy Document.

[36] Loos, J., Abson, D., Chappell, M., Hanspach, J., Mikulcak, F., Tichit, M., Fischer, J. (2014). Putting Meaning Back into "Sustainable Intensification". Frontiers in Ecology and the Environment, 12(6), 356-361.

[37] Reardon, T., Kelly, V., Crawford, E. (1995). Promoting Investment in Sustainable Intensification of African Agriculture. Michigan State University Press.

[38] FAO (2016). Nigeria at a Glance. [Online] Available at: http://www.fao.org/nigeria/fao-in-nigeria/nigeria-at-a-glance/e $\mathrm{n} /$ [Accessed 19 July 2016].

[39] Arid, A. (2010). Policies for Reduced Deforestation and Their Impact on Agricultural Production. Proceedings of the National Academy of Sciences of the United States of America, 107(46), 19639-19644.

[40] Awotide, B., Abdoulaye, T., Alene, A., Manyong, V. (2015). Impact of Access to Credit on Agricultural Productivity: Evidence from Small Holder Cassava Farmers in Nigeria. International Conference of Agricultural Economics (ICAE), Milan, Italy. 
[41] Jerome, A. (2012). Nigeria's Food Security Programs: Implications for MDG's Goal of Extreme Hunger Eradication. International Journal of Business and Social Science, 3(9), 243-247.

[42] Olowa, O., Olowa, O. (2014). Policy Interventions and Public Expenditure Reform for Pro-Poor Agricultural Development in Nigeria. African Journal of Agricultural Research, 9(4), 487-500.

[43] Sanchez, P. (2010). Tripling Crop Yields in Tropical Africa. Nature Geoscience, 3(May), 299-300.

[44] Liverpool-Tasie, S., Olaniyan, B., Salau, S., Sackey, J. (2010). A Review of Fertilizer Policy Issues in Nigeria. Nigeria Strategy Support Program, Working Paper No. 0019. International Food Policy Research Institute (IFPRI).

[45] You, L., Ringler, C., Wood-Sichra, U., Robertson, R., Wood, S., Zhu, Tingju., Nelson, G., Guo, Z., Sun, Y. (2011). What is the Irrigation Potential for Africa? A Combined Biophysical and Socioeconomic Approach. Food Policy, 36, 770-782.
[46] Inocencio, A., Kikuchi, M., Tonosaki, M., Maruyama, A., Merrey, D., Sally, H., Jong, I. (2007). Costs and Performance of Irrigation Projects: A Comparison of Sub-Saharan Africa and Other Developing Regions. International Water Management Institute.

[47] Otoko, G., Fubara-Manuel, I. (2014). Analyses of the Mechanisms Behind changes in Land Use in Nigeria. International Journal of Engineering Sciences and Research Technology, 3(4), 5025-5031.

[48] Philip, T., Taylor, D., Sami, L., Akoroda, M. (2004). A Cassava Industrial Revolution in Nigeria: The Potential for a New Industrial Crop. International Fund for Agriculture; FAO, Rome.

[49] Federal Ministry of Agriculture and Rural Development (2015). Annual Report.

[50] Tscharntke, T., Klein, A., Kruess, A., Steffan-Dewenter, I., Thies, C. (2005). Landscape Perspective on Agricultural Intensification and Biodiversity Ecosystem Service Management. Ecology Letters, 8(8), 857-874. 